\title{
SPORTS AND COMBAT SAMBO EXPOSURE AND DIFFERENCES IN STAGE-ACTIVITY
}

\author{
Stanislav Dadelo ${ }^{1}$, Algis Mečkovskis ${ }^{2}$, Edmundas Štarevičius ${ }^{2}$ \\ Vilnius Gediminas Technical University ${ }^{l}$, Vilnius, Lithuania \\ Mykolas Romeris University'2, Vilnius, Lithuania
}

\begin{abstract}
Research background and hypothesis. The sport result is mostly accounted for by the technical and tactic preparation of SAMBO fighters. The establishment of the Sports and Combat SAMBO wrestling contest actions will allow identifying the essential differences between the ways of wrestling.

Research aim was to examine the distribution of actions used by Lithuanian Sport and Combat SAMBO fighters exhibiting different sport skill levels at contests differing in terms of their level.

Research methods. In 2012 we watched 46 Lithuanian higher school Sport SAMBO contest bouts and analysed 50 Lithuanian Sport SAMBO Championship bouts and 43 Combat SAMBO bouts.

Research results. Actions performed at Sport SAMBO were relatively divided into: very important - throws by legs and throws by trunk; important - throws by arms and retention; of minor importance - painful arm locks and painful leg locks. Combat SAMBO wrestling actions were divided into: very important - throws by arms, retention and throws by trunk; important - throws by legs, painful arm locks; of minor importance - painful leg locks.

Discussion and conclusions. In stage-activity, the arsenal of greater mastery SAMBO wrestling moves and combinations is larger, therefore the process of drafting motion management training should be the main objective. Throws performed on stage by Sports and Combat SAMBO wrestling wrestlers have major differences. Sport SAMBO is based on a large variety off throws, in sport SAMBO the throw is attempted by feet or waist, and combat SAMBO wrestling is based on hand throws, throws around the waist, maintenance, leg locks and arm bars.
\end{abstract}

Keywords: competition stenography, range of actions, effectiveness of actions.

\section{INTRODUCTION}

$\mathrm{L}$ ithuanian sportspeople have gained remarkable achievements in combat sports at the European and World championships and the Olympic Games. A wide range of wrestling types, the complexity of movement control, a variety of training measures and methods as well as their scientific substantiation is becoming an increasingly urgent problem for the comprehensive development of younger generation and further advancement of sport (Skurvydas, 2008; Skernevičius et al., 2011; Kenney et al., 2012).

Science investigates the range, choice and performance of movements used in wrestling under definite circumstances. Extensive analysis of the movement control problems is made; however, a single opinion about these issues is still missing (Körding et al., 2007; Latash et al., 2007; Skurvydas, 2008). Wrestling types are numerous, separate types sometimes develop their different branches and events.

SAMBO is a relatively young branch of sport. Since 1972 international SAMBO contests have been organised on a regular basis. Since 2002 SAMBO wrestling has been divided into the sport and combat events. In Lithuania, Sport and Combat SAMBO actions and their application have been widely analysed (Linonis at al., 2004; Štarevičius, Mečkovskis, 2012). However, Lithuanian 
researchers usually inquire into the problems of college student sport. Within the wide space of research there are studies showing that the range of actions used by SAMBO fighters differs depending on the level of their skills (Буланцов, Табаков, 2011; Горская, Конондаков, 2012). Studies focusing on the specific features of actions used by Sport and Combat SAMBO fighters differing in terms of their skills are not sufficiently numerous. The technical and tactic preparedness of SAMBO fighters produces the most significant effect on the sport result (Фёдоров, 2008). Teaching how to apply fight actions adequately plays a vital role in the training of wrestlers (Дажалилов, 2010). SAMBO develops intensively; the popularity of this particular branch of sport is growing steadily. Within the world context, SAMBO demands serious attention from sport researchers, however, the number of studies in this area is still insufficient. Without research and data analysis the control of basic training parameters, such as the performance, intensity and volume of actions, becomes complicate. It is impossible to control the process of fighter preparation effectively unless the target research information concerning training and contests is available; this factor vitally affects the training procedure for the purpose of achieving progress in sport (Naglak, 1977; Skernevičius et al., 2011).

It is relevant to determine and analyse the qualitative and quantitative indicators of technical actions used by SAMBO contestants. This should help to optimise the training process involving SAMBO fighters taking into account the specific features of their contest activities. It is equally important to carry out a comparative analysis of the technical action performance indicators shown at Sport and Combat SAMBO contest bouts. This could help to set up the fighter training landmarks for more purposeful application of actions in the selected discipline.

The following research problem emerges: to inquire into and reveal a variety of actions used by Sport and Combat SAMBO fighters differing in terms of their sport skill level.

Research purpose: to examine the distribution of actions used by Lithuanian Sport and Combat SAMBO fighters exhibiting different sport skill levels at contests differing in terms of their level.

Research object: technical actions applied at Sport and Combat SAMBO fighter contests of differing level.
Hypothesis: the dissemination of actions in Sports and Combat SAMBO wrestling contest will allow to identify the essential differences between the ways of wrestling. This will provide a basis for efficient planning and management of Sports and Combat SAMBO wrestling training.

\section{RESEARCH METHODS}

In 2012 we watched 46 Lithuanian college student Sport SAMBO bouts; we also examined 50 Lithuanian Sport SAMBO Championship bouts and 43 Combat SAMBO bouts. Efficacious (evaluated by judge) actions were recorded by means of a stenography method (Чумаков, 1976). Classification of SAMBO actions was carried out according to J. Gorskaja, M. Kondakov (2012) methodology. Significance of the data distribution difference was checked by calculating $\chi$-square $\left(\chi^{2}\right)$ (Čekanavičius, Murauskas, 2000). We applied the four field $(2 \times 2)$ frequency table calculation method (Pukènas, 2009). For the determination of reliability of data elicited from the separate sample indicators, we applied $\mathrm{p}<0.05$ and $\mathrm{p}<0.01$ criteria. Computation was performed with the help of SPSS package.

\section{RESEARCH RESULTS}

Research indicated that the rate of application of technical actions used by contestants and evaluated by judges per bout at college student Sport SAMBO Championship, compared to the one at Lithuanian Championship, amounted to 2.50 and 3.32 respectively (Table 1). Evaluation of activity demonstrated by sportspeople during bouts allows us to assume that Lithuanian SAMBO Championship contestants may be evaluated as sathletes with a higher level of skills. It was found that at the Lithuanian Championship, compared to college student contest, the rate of actions performed and evaluated by judges is larger by approximately 0.82 . However, this difference is not reliable $\left(\chi^{2}=0.27 ; p>0.05\right)$. The distribution of categories of actions performed at both contests is similar. However, at Lithuanian SAMBO Championship the frequency of throws by arms and throws by legs performed by fighters exceeds the rate demonstrated by the participants of Lithuanian SAMBO college student championship by approximately $2 \%$. Throws by trunk movement or a less complicated over the back throw with 
arm clinch are more acceptable at college student contests. Other actions which are evaluated as more complex ones are performed mostly by Lithuanian championship participants. Static actions (painful arm lock and retention) are preferred by Lithuanian Championship contestants; however, painful leg locks are more acceptable at college student contests.

Actions performed at Sport SAMBO Lithuanian contests may be divided relatively into three groups (Table 2): Group 1 (very important actions) - throws by legs (33\%) and throws by trunk (30\%), these constitute the largest part of efficaciously performed actions (63\%); Group 2 (important actions) - throws by arms (14\%) and retention (13\%); Group 3 (actions of minor importance) - painful arm locks (5\%) and painful leg locks (4\%). A particular group consists of actions performed most frequently, of them at least one action is performed efficaciously once per each contest bout on the average (over the back throw from the knee, front or back leg-show throw, over the pelvis throw, throw with both legs clinch). These actions represent the basis of technique in the SAMBO contest activities.

Evaluation of the distribution of Combat SAMBO actions at Lithuanian Championship indicates a higher level of athlete's activity. Each Combat SAMBO contestant average performed on 3.89 actions per bout compared to Sport SAMBO contest indicators, this is a 0.96 increase on judge evaluated action. Yet it must be noted that about $23 \%$ of judge evaluated Combat SAMBO bout actions consisted of blow-involving actions

Table 1. Distribution of actions performed and evaluated by judges at Lithuanian higher schools and adults Sport SAMBO contests; reliability of the value differences

\begin{tabular}{|c|c|c|c|c|c|}
\hline No. & $\begin{array}{l}\text { Action } \\
\text { groups }\end{array}$ & Actions & $\begin{array}{c}\text { Higher } \\
\text { schools } \\
\text { SAMBO }\end{array}$ & $\begin{array}{c}\text { Lithuanian } \\
\text { adults } \\
\text { SAMBO }\end{array}$ & $\begin{array}{l}\text { Action difference } \chi^{2} \\
\text { and reliability values }\end{array}$ \\
\hline \multirow{4}{*}{1.} & \multirow{4}{*}{$\begin{array}{l}\text { Throws } \\
\text { by arms }\end{array}$} & With both legs clinch (n) & 8 & 12 & \\
\hline & & Knocking off (n) & 5 & 9 & \\
\hline & & ,Windmill“‘ (n) & 2 & 4 & \\
\hline & & In total $(\mathrm{n}, \%)$ & $15(13)$ & $25(15)$ & $0.29(\mathrm{p}>0.05)$ \\
\hline \multirow{7}{*}{2.} & \multirow{7}{*}{$\begin{array}{l}\text { Throws } \\
\text { by legs }\end{array}$} & Back leg-show (n) & 15 & 6 & \\
\hline & & Front leg-show (n) & 5 & 16 & \\
\hline & & Lateral undercut (n) & 5 & 8 & \\
\hline & & Inside pickup (n) & 4 & 9 & \\
\hline & & Overhead with knee rest (n) & 6 & 10 & \\
\hline & & Overhead with foot rest (n) & 2 & 7 & \\
\hline & & In total $(n, \%)$ & $37(32)$ & $56(34)$ & $0.12(\mathrm{p}>0.05)$ \\
\hline \multirow{7}{*}{3.} & \multirow{7}{*}{$\begin{array}{l}\text { Throws } \\
\text { by trunk }\end{array}$} & Over the pelvis (n) & 8 & 12 & \\
\hline & & Over the back with arm clinch (n) & 10 & 6 & \\
\hline & & Drop throw (n) & 4 & 7 & \\
\hline & & Over the back from the knee (n) & 7 & 15 & \\
\hline & & Spring hip (n) & 5 & 5 & \\
\hline & & Undercut while falling (n) & 1 & 5 & \\
\hline & & In total $(n, \%)$ & $35(30)$ & $50(30)$ & $0.00(\mathrm{p}>0.05)$ \\
\hline 4. & \multicolumn{2}{|c|}{ Painful arm lock (n, \%) } & $6(5)$ & $9(5)$ & $0.00(\mathrm{p}>0.05)$ \\
\hline 5. & \multicolumn{2}{|c|}{ Painful leg lock (n, \%) } & $6(5)$ & $5(3)$ & $1.01(\mathrm{p}>0.05)$ \\
\hline 6. & \multicolumn{2}{|c|}{ Retention (n, \%) } & $16(14)$ & $21(13)$ & $0.07(\mathrm{p}>0.05)$ \\
\hline \multicolumn{3}{|c|}{ Overall (n, \%) } & $115(100)$ & $166(100)$ & \\
\hline
\end{tabular}


(128 wrestling actions and 29 blow-involving actions were recorded during the bouts). Comparison of the distribution of wrestling actions performed during the observed Combat SAMBO and Sport SAMBO contests showed essential differences in almost all action groups $(\mathrm{p}<0.05)$. The difference was not observed only in painful leg locks (Figure 1). Combat SAMBO bouts were distinguished for throws by arms (29\%), their performance rate was twice as big as in Sport SAMBO bouts $\left(\chi^{2}=10.69\right.$; $\mathrm{p}<0.01$ ) (Table 2) in which a throw with both legs clinch prevailed. Throws by trunk take the second place in throws from the point of view of application in Combat SAMBO bouts $-20 \%$ of all performed actions, however the per cent rate of application of these actions is lower by one third in comparison with the one observed at Sport
SAMBO contests $\left(\chi^{2}=4.03 ; \mathrm{p}<0.01\right)$. A huge difference between Combat and Sport SAMBO bouts is evident in throws by legs $\left(\chi^{2}=15.81\right.$; $\mathrm{p}<0.01$ ). In Sport SAMBO bouts these actions are performed twice as frequently. Painful arm locks and retention involving static actions dominate Combat SAMBO bouts in absolute and relative figures $(\mathrm{p}<0.01)$. Combat SAMBO wrestling actions, by the frequency of performance in contest activities may be divided into: 1. very important (throws by arms (29\%), retention (23\%) and throws by trunk (20\%)). To these actions take the largest share of efficaciously-performed actions (72\%); 2. important (throws by legs (14\%), painful arm locks (11\%)); 3. of minor importance: painful leg locks $(2 \%)$.

Table 2. Distribution of actions performed at Lithuanian Sport SAMBO and Combat SAMBO contests; reliability of the value differences

\begin{tabular}{|c|c|c|c|c|c|}
\hline No. & $\begin{array}{l}\text { Action } \\
\text { groups }\end{array}$ & Actions & $\begin{array}{c}\text { Lithuanian } \\
\text { higher schools } \\
\text { and adults } \\
\text { Sport SAMBO }\end{array}$ & $\begin{array}{c}\text { Lithuanian } \\
\text { Combat } \\
\text { SAMBO }\end{array}$ & $\begin{array}{c}\text { Sport SAMBO and } \\
\text { Combat SAMBO } \\
\text { action difference } \chi^{2} \\
\text { and reliability values }\end{array}$ \\
\hline \multirow{4}{*}{1.} & \multirow{4}{*}{$\begin{array}{l}\text { Throws } \\
\text { by arms }\end{array}$} & With both legs clinch (n) & 20 & 21 & \\
\hline & & Knocking off (n) & 14 & 3 & \\
\hline & & „Windmill“‘ (n) & 6 & 1 & \\
\hline & & In total $(\mathrm{n}, \%)$ & $40(14)$ & $26(29)$ & $10.69(\mathrm{p}<0.01)$ \\
\hline \multirow{7}{*}{2.} & \multirow{7}{*}{$\begin{array}{l}\text { Throws } \\
\text { by legs }\end{array}$} & Back leg-show (n) & 21 & 4 & \\
\hline & & Front leg-show (n) & 21 & 2 & \\
\hline & & Lateral undercut (n) & 13 & 1 & \\
\hline & & Inside pickup (n) & 13 & 5 & \\
\hline & & Overhead with knee rest (n) & 16 & 1 & \\
\hline & & Overhead with foot rest (n) & 9 & 0 & \\
\hline & & In total $(\mathrm{n}, \%)$ & $93(33)$ & $13(14)$ & $15.81(\mathrm{p}<0.01)$ \\
\hline \multirow{7}{*}{3.} & \multirow{7}{*}{$\begin{array}{l}\text { Throws } \\
\text { by trunk }\end{array}$} & Over the pelvis (n) & 20 & 1 & \\
\hline & & Over the back with arm clinch (n) & 16 & 1 & \\
\hline & & Dropthrow (n) & 11 & 1 & \\
\hline & & Over the back from the knee (n) & 22 & 3 & \\
\hline & & Spring hip (n) & 10 & 12 & \\
\hline & & Undercut while falling (n) & 6 & 0 & \\
\hline & & In total $(\mathrm{n}, \%)$ & $85(30)$ & $18(20)$ & $4.03(\mathrm{p}<0.01)$ \\
\hline 4. & \multicolumn{2}{|c|}{ Painful arm lock (n, \%) } & $15(5)$ & $10(11)$ & $4.61(\mathrm{p}<0.01)$ \\
\hline 5. & \multicolumn{2}{|c|}{ Painful leg lock (n, \%) } & $11(4)$ & $2(2)$ & $1.36(\mathrm{p}>0.05)$ \\
\hline 6. & \multicolumn{2}{|c|}{ Retention (n, \%) } & $37(13)$ & $21(23)$ & $5.63(\mathrm{p}<0.01)$ \\
\hline \multicolumn{3}{|c|}{ Overall (n, \%) } & $281(100)$ & $128(100)$ & \\
\hline
\end{tabular}


Figure. Distribution of the indicators of actions performed at Lithuanian SAMBO contests, in per cent

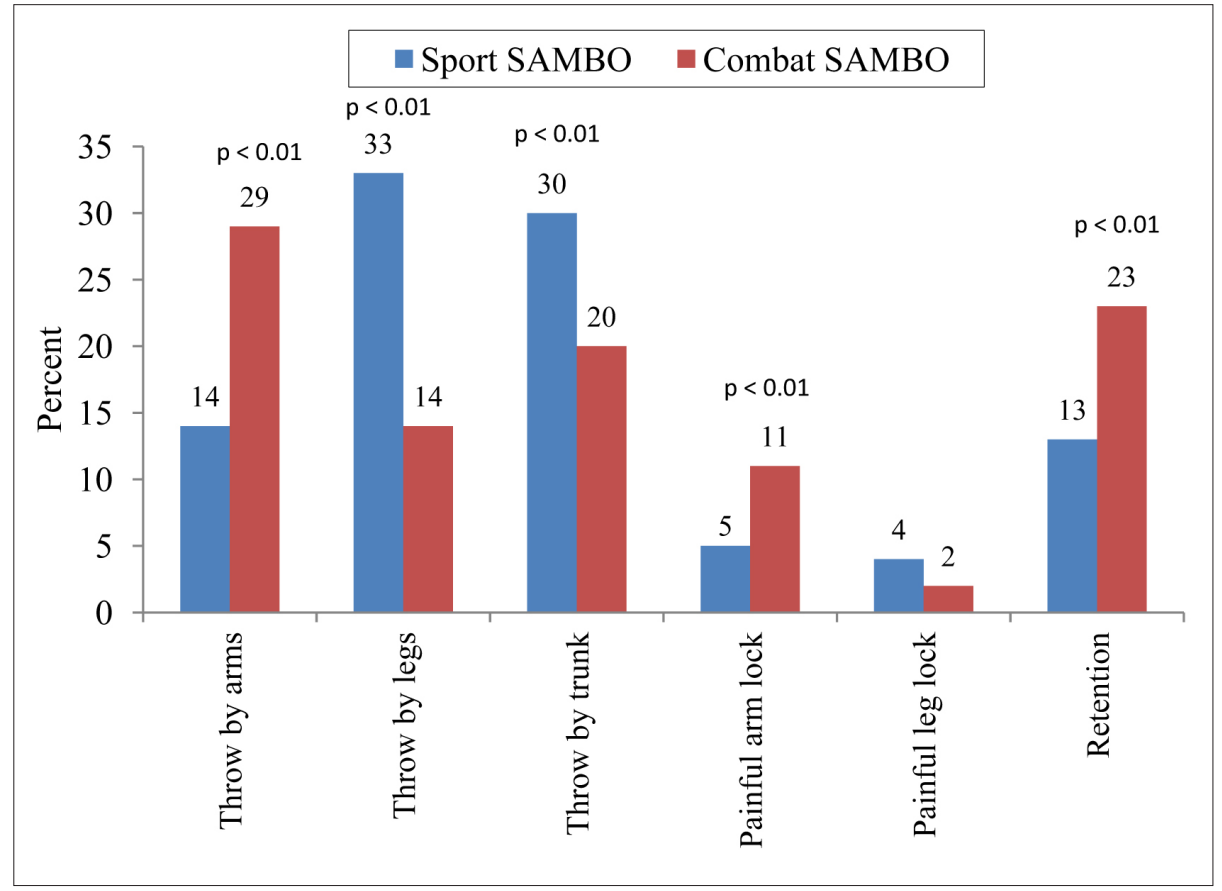

\section{DISCUSSION}

Research showed that contestants performed a bigger number of dynamic actions (throws) at Lithuanian Sport SAMBO higher level contests; the application of static actions (painful locks and retention) did not differ much. S. Dažalilov (2010), S. Fedorov et al. (2012) having examined young SAMBO fighters, found that the fostering of fighters' activity during their training sessions by a variety of methodological measures speeded up the progress in movement control and sports skill. Studies indicated that among the five major factors determining the SAMBO bout result, the most important one was the technique-tactics factor; also important were physical abilities, such as swiftness and equilibrium which form the basis of movement control (Осипов, 2012). Research carried out by other authors revealed that the specific characteristics of SAMBO fighters' technical and tactic training and their bout performance were strongly influenced not only by the weight category indicators but also by the morphological body features; this is especially important to the fighters belonging to heavy weight categories (Горская, Кондаков, 2012).

The data of our research involving Lithuanian SAMBO fighters support the findings by foreign researchers who examined highly skilled fighters
(Буланцов, Табаков, 2011): the control and abundance of movements determine the level of athlete's skill. The level of technical-tactical and specific physical preparedness of fighters as well as the rules of this particular sport event account for the bout contents determining the specific features of training. The combat scope of actions used by fighters is much smaller compared to the total range of mastered actions (Харитонашвили и др., 2007). With the growth of importance and level of a contest, sportspeople increasingly seek to avoid risk and perform only reliable actions able to secure a victory without experiencing a dangerous position (Журавель и др., 2003). Original data elicited by this research through the comparison of the range of actions used by Sport and Combat SAMBO fighters enrich the training research knowledge which may help to improve the training of fighters. It must be stressed that the groups of very important and important factors determined in our research are characterised by diversity and performance-related combinatory chances (chance to go from the performance of one action to another with lightning speed). This information must be taken into account when carrying out the pre-contest training of fighters. 


\section{CONCLUSIONS AND PERSPECTIVES}

In stage-activity, the arsenal of greater mastery SAMBO wrestling moves and combinations is larger; therefore, the process of drafting movement management training should be the main objective. Sports and Combat SAMBO wrestling wrestlers' performed throws on stage have major differences. Sport SAMBO is based on a large variety of throws, in sport SAMBO throw is attempted with feet or waist, and combat SAMBO wrestling is based on hand throws, throws around the waist, maintenance, leg locks and arm bars. Sports and Combat SAMBO wrestling training is applied by different steps and combinations highlighting specific areas.

\section{REFERENCES}

Čekanavičius, V., Murauskas, G. (2000). Statistika ir jos taikymai. I dalis. Vilnius: TEV.

Kenney, W. L., Wilmore, J., Costill, D. (2012). Physiology of Sport and Exercise. With Web Study Guide-5th Edition. Human Cinetics.

Körding, K. P., Tenenbaum, J. B., Shadmechr, R. (2007). The dynamics of memory as a consequence of optimal adaptation to a changing body. Nature Neuroscience, 10, 779-786.

Latash, M. L., Sholz, J. P., Schoner, G. (2007). Toward a new theory of motor synergies. Motor Control, 11, 276-308.

Linonis, V., Mikalauskas, R., Obcarskas, L. (2004). Sambo imtynių varžybu vaidmuo statutiniu tarnybu pareigūnų rengimo procese. Jurisprudencija, 62 (54), 59-65.

Naglak, Z. (1977). Trening sportowy. Teoria i praktyka. Warszawa: Wrodaw, PWN.

Pukènas, K. (2009). Kokybiniu duomenu analizès SPSS programa. Kaunas: LKKA.

Skernevičius, J., Milašius, K., Raslanas, A., Dadelienè, R. (2011). Sporto treniruotè: monografija. Vilnius: VPU.

Skurvydas, A. (2008). Judesiu mokslas: raumenys, valdymas, mokymas, reabilitavimas, sveikatinimas, treniravimas, metodologija: vadovèlis. Kaunas: LKKA.

Štarevičius, E., Mečkovskis, A. (2012). Sambo imtyniu vaidmuo studentu rengimo procese. Visuomenès saugumas ir viešoji tvarka, 7, 222-235.

Буланцов, А. М., Табаков, С. Е. (2011). Сравнение показателей технико-тактической подготовленности сборных команд России по самбо к чемпионату мира и к чемпионату Европы 2009 года. Учёные записки, 4 (74), 19-22.

Горская, И. Ю., Кондаков, А. М. (2012). Необходимость учёта морфологических различий в процессе физической и технико-тактической подготовки самбистов. Омский научный вестник, 4 (111), 229-233.

Дажалилов, С. А. (2010). Показатели техникотактической подготовленности начинающих борцов самбистов в условиях соревновательной деятельности. Учёные записки, 4 (62), 27-30.

Журавель, А. В., Закорко, И. П., Скирта, Р. И. (2003). Изучение состава технических действий в дзюдо на соревновательном этапе его развития.

C. С. Ермакова (ред.), Физическое воспитание студентов творческих специальностей: сб. научн. mp. ХГАДИ (ХХПИ), 2, 47-52.

Осипов, А. Ю. (2011). Совершенствование технического мастерства борцов. Вестник Казанского технологического университета, 3, 174176.

Фёдоров, С. Л., Григорев, С. А., Кузнецов, В. П., Воробёв, С. А., Архипова, Ю. А. (2012). Особенности построения подготовки спортсменов с учётом индивидуального соревновательного опыта в единоборствах. Культура физическая и здоровье, 4, 73-75.

Фёдоров, С. Л. (2008). Структура и модельные характеристики технико-тактической подготовленности спортсменов занимающихся борьбой самбо. Учёные записки, 12 (46), 86-90.

Харитонашвили, К., Чахунашвили, А., Будзишвили, Н. (2007). Техническая и тактическая подготовка дзюдоистов. С. С. Срмакова (ред.), Педагогіка, психологія та медико-біологічні проблеми фізичного виховання і спорту: зб. наук. пращь. ХДАДМ (ХХПІ), $11,85-87$.

Чумаков, Е. М. (1976). Тактика бориа самбиста. Москва: Физкультура и спорт. 


\title{
SPORTINIO IR COMBAT SAMBO TECHNIKOS VEIKSMU VARŽYBINĖJE VEIKLOJE SKLAIDA IR SKIRTUMAI
}

\author{
Stanislav Dadelo ${ }^{1}$, Algis Mečkovskis ${ }^{2}$, Edmundas Štarevičius $^{2}$ \\ Vilniaus Gedimino technikos universitetas, Vilnius, Lietuva \\ Mykolo Romerio universitetas, Vilnius, Lietuva
}

\section{SANTRAUKA}

Tyrimo pagrindimas ir hipotezé. Trūksta moksliniu tyrimų, kurie atskleistu i̇vairaus sportinio lygmens imtynininkų sportinio ir Combat SAMBO veiksmų ypatumus. SAMBO imtynininkų techninis, taktinis parengtumas daugiausia turi itakos sportiniam rezultatui. Svarbu nustatyti SAMBO imtynininkų technikos veiksmų varžybineje veikloje kokybinius ir kiekybinius rodiklius, atlikti jų analizę. Nustačius ịvairaus meistriškumo SAMBO imtynininkų varžybose taikomų veiksmų sklaida, bus galima veiksmingiau planuoti ir valdyti sportininkų rengimą.

Tikslas - ištirti Lietuvos sportinio ir Combat SAMBO įvairaus meistriškumo sportininkų skirtingo lygmens varžybose taikomų veiksmų sklaidą.

Metodai. 2012 metais stebėjome Lietuvos aukštujų mokyklų sportinio SAMBO varžybų 46 kovas ir ištyrème 50 Lietuvos sportinio SAMBO čempionato kovu bei 43 Combat SAMBO kovas.

Rezultatai. Sportinio SAMBO Lietuvos varžybose atliekamus veiksmus sąlygiškai galima suskirstyti į: labai svarbius - metimus kojomis ir metimus liemeniu; svarbius - metimus rankomis ir išlaikymą; mažai svarbius skausmingus veiksmus rankai ir skausmingus veiksmus kojai. Combat SAMBO imtynių veiksmai skirstomi ị: labai svarbius - metimus rankomis, išlaikymą ir metimus liemeniu; svarbius - metimus kojomis, skausmingus rankai; mažai svarbius - skausmingus kojai.

Aptarimas ir išvados. Varžybineje veikloje didesnio meistriškumo SAMBO imtynininkų judesių ir jų kombinacijų i̇vairovè yra didesnè, rengimo procese judesių valdymo mokymas turètų būti labai svarbus. Sportinio ir Combat SAMBO imtynininkų veiksmai varžybų metu turi esminių skirtumų. Sportinio SAMBO pagrindą sudaro metimai kojomis ir metimai liemeniu, o Combat SAMBO - metimai rankomis, išlaikymas ir metimai liemeniu. Rengiant sportinio ir Combat SAMBO imtynininkus taikomi skirtingi veiksmai ir jų kombinacijos.

Raktažodžiai: varžybų stenografija, veiksmų ịvairovè, veiksmingumas.

Gauta 2013 m. balandžio 13 d.

Received on April 13, 2013 